\title{
Structural Performance Of High Strength Concrete Columns In Fire
}

Faris A. Ali, Ali Nadjai, Paul Glackin, Gordon Silcock, University of Ulster, Shore Road, Jordanstown, BT37 OQB, UK.

Abid Abu-Tair, Al-Qudus University, Jerusalem.

\begin{abstract}
Current concrete design Codes raise concerns about concrete spalling during fire particularly under compressive stresses and high heating rates. High strength concrete columns would be more prone for explosive spalling due to their low permeability and high brittleness. This paper represents an experimental program on the behavior of high strength concrete columns under fire. The research includes testing reinforced high strength concrete columns subjected to various loading levels and heating rates. Eighteen columns were tested under four loading levels and two heating rates. The paper represents the main results including the measured concrete and steel temperatures and axial displacements. The paper includes also the results of testing extra 12 high srength columns executed to enhance the experimental program and to verify more precisely the effect of loading level on the structural performance of high strength concrete columns in fire. Valuable conclusions on the effect of loads and heating on concrete explosive spalling are shown in the paper.
\end{abstract}

Keywrds: High-strength concrete, fire, explosive spalling, columns, heating rate, axial loads

\section{INTRODUCTION}

Concrete spalling under high temperatures is a major factor of reducing it's fire resistance. Disintegration of concrete parts due to spalling can cause serious reduction in the cross section of structural elements and could lead to early catastrophic failure. Explosive spalling is the most dangerous type of concrete spalling. It happens with high explosive energy causing concrete shrapnels to fly with high speed, causing more casualties and damage to the surrounding environment including smashing adjacent windows and thereby letting more oxygen to get into the fire area and increase the severity of the fire. Moreover, Euro-Tunnel Channel fire in 1996 showed that, explosive spalling can threaten the integrity of the whole structure and lead to total structural collapse. This raises serious concerns about studying this phenomenon and identifying the infl uencing factors and methods of preventing explosive spalling.

Explosive spalling happens due to high pore pressure inside the concrete. During concrete exposure to fire, free and combined water inside the concrete starts to evaporate. If the concrete has a low permeability, the pore pressure starts to build up and induces stresses on the internal structure of the concrete. Vapor stresses can build up to high levels with temperature increase and if these stresses overcome the tensile strength of the concrete, local failure happens releasing high energy and leading to a chain of concrete micro-structural failure in the adjacent parts and violent explosion of concrete takes place.

Valuable research was performed on concrete in the past by many investigators including Malhotra [13], Dougill [9] Sullivan et.al. [1], Hetrs et.al. [10], Shirly et.al. [16], Sanjanyn et.al. [15], Jumppannen et.al. [11], Connolly [6] , Castillo et.al. [5], Franssen et.al. [2] and others [7,8,12,14]. In a study by Ali et al. [3] a useful summary of previously performed research on high strength concrete behavior under high temperatures is discussed. The research [3] showed that high strength concrete is more prone to explosive spalling than normal strength concrete due to its high density and low permeability. The paper [3] indicates also that several studies attempted to identify factors effecting explosive spalling including material property factors, heating, boundary conditions, geometrical factors and others where researchers reported a contradictive spalling behavior under high temperatures [3]. Moreover, most of the previous investigations studied individual cases and mainly focused on 
studying the effects of material factors on spalling. Despite that some investigations [2,12] considered the effect of loads on explosive spalling of high strength concrete columns, the effect of other boundary condition factors including restraint and loading is still poorly examined in general. This has motivated the authors to perform a parametric study on behavior of high strength concrete column under fire considering the effect of loading levels, restraint, heating rates and focusing on explosive spalling. The experimental project (which is anticipated to involve some 100 high strength concrete columns) is still going at present and an important part, which includes the effect of loading and heating on explosive spalling, has been completed.

\section{RESEARCH SIGNIFICANCE}

The objective of this paper is to report the main outcomes of a parametric experimental study on the effect of loading and heating rates on explosive spalling of high strength concrete columns in fire. The tests were performed at the Fire Research Laboratories, the University of Ulster, UK. The paper includes the test methodology, main results, conclusions and measured parameters including temperatures and axial displacement of high strength concrete columns.

\section{THE EXPERIMENTAL PROGRAM}

The experimental program was designed to cover rational range of loading levels and heating rates. The tests involved 18 reinforced concrete columns of a section $127 \mathrm{mmx} 127 \mathrm{~mm}$ and $1800 \mathrm{~mm}$ height. Each column was reinforced with four $12 \mathrm{~mm}$ diameter steel bars as shown in Fig. 1 and connected with twenty steel ties $(6 \mathrm{~mm}$ diameter) at $120 \mathrm{~mm}$ intervals in the middle and $60 \mathrm{~mm}$ at the ends. Ties were located more often near the ends to prevent any possible local column failure near the loading points.

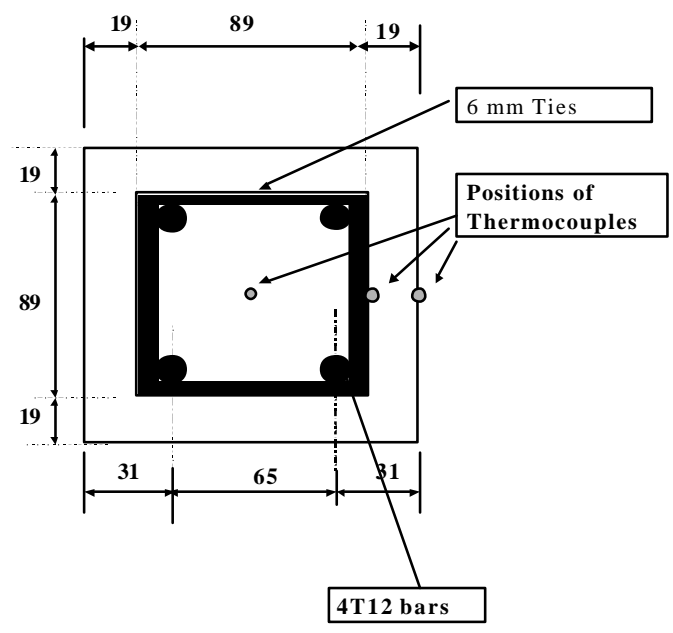

Figure 1. Columns section and position of temperature measurements

\section{Tests Parameters}

Three high strength concrete columns were tested for each case. The total tested columns were 18 representing 6 cases. All the columns were tested at average age $=100$ days. The columns were simply supported at both ends and were tested under three loading levels 0.2, 0.4 and 0.6 of the design load of BS8110. Each column was tested under two heating regimes. The two fire curves used in column testing are shown in Fig. 2. The first curve represents the BS476 fire curve and is defined as the "high heating rate". The second curve had an inferior intensity and is defined as the "low heating rate". For example, under high heating rate the furnace temperature reaches $600^{\circ} \mathrm{C}$ in 6 minutes while it takes almost 40 minutes to reach this temperature under the low heating 
regime. The two heating curves were produced using a powerful burner, which operates on propane gas, and the burner was manually controlled to match the desired heating rate.

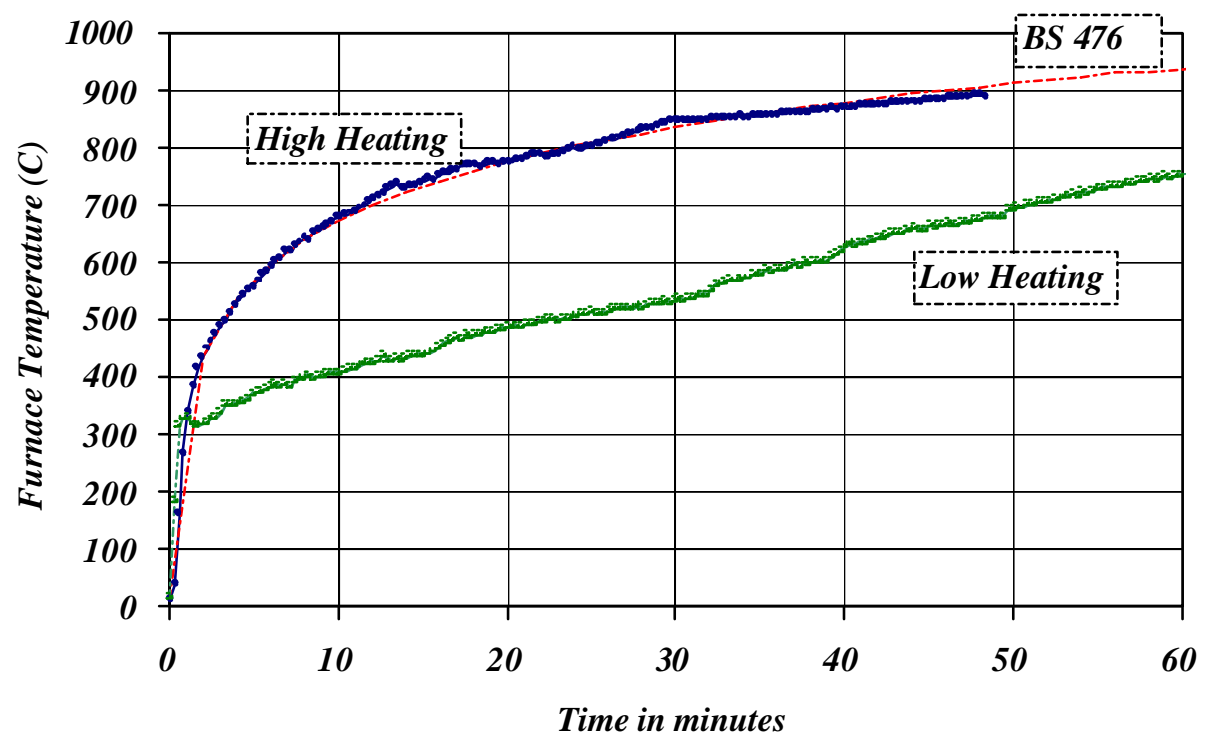

Figure 2. Time temperature curves used in the tests

\section{High Strength Concrete Mix}

It was anticipated to produce a concrete of a mid range strength on the high strength concrete scale. The planned strength was between 90 and $110 \mathrm{~N} / \mathrm{mm}^{2}$ (at 28 days). This is a concrete strength that is more often used in high strength concrete building industry. The processes of producing high strength concrete involved 28 trial mixes with water/cement ratios ranged between $0.2-0.35$. Mixes with water contents $\geq 140 \mathrm{~kg}$ in one $\mathrm{m}^{3}$ of concrete showed higher strength. Consequently, a mix with proportions shown in Table 1 was chosen to produce concrete strength at 28 days $=106 \mathrm{~N} / \mathrm{mm}^{2}$. Ordinary Portland Cement and dry silica fume powder were used. A river sand and crushed basalt aggregates of maximum size $=10 \mathrm{~mm}$ in SSD (Saturated Surface Dry) case was utilized in the mixes. All the specimens were cured for 7 days in water and then covered with plastic sheets where an environmental humidity $=60-75 \%$ was maintained for nearly 3.5 months when the fire tests were to be performed. Eighteen columns in total were cast together with $100 \mathrm{mmx} 100 \mathrm{~mm}$ concrete cubes to determine the compressive strength at 28 and 100 days which represents the age of columns testing. The average strength of concrete obtained at 28 days $=104.5 \mathrm{~N} / \mathrm{mm}^{2}$ and $119 \mathrm{~N} / \mathrm{mm}^{2}$ for 100 days. The cubes showed excellent consistency with a coefficient of variation value $=1.69 \%$ for 28 days age cubes and $1.9 \%$ fr 100 days age. The average water contained in concrete by mass $=5-5.8 \%$ at the testing age $=100$ days. 
Table 1. HSC mix proportions

\begin{tabular}{|c|c|}
\hline Ingredient & Quantity \\
\hline Water $\left(\mathrm{L} / \mathrm{m}^{3}\right)$ & 130 \\
\hline Cement $\left(\mathrm{kg} / \mathrm{m}^{3}\right)$ & 447 \\
\hline Fine aggregate $\left(\mathrm{kg} / \mathrm{m}^{3}\right)$ & 672 \\
\hline Coarse aggregate, $\left(\mathrm{kg} / \mathrm{m}^{3}\right)($ Basalt $)$ & 1098 \\
\hline Silica Fume $\left(\mathrm{kg} / \mathrm{m}^{3}\right)$ & 44 \\
\hline superplastisizer $\left(\mathrm{L} / \mathrm{m}^{3}\right)$ & 15 \\
\hline Water/Cement & 0.29 \\
\hline Water $/($ Cement + Silica) & 0.26 \\
\hline Strength at 7 days $\left(\mathrm{N} / \mathrm{mm}^{2}\right)$ & 86 \\
\hline Strength at 28 days $\left(\mathrm{N} / \mathrm{mm}^{2}\right)$ & 106 \\
\hline
\end{tabular}

\section{Data Measurements}

To measure the temperatures, each column had two thermocouples cast in. The first one was located at the center of the cross section and the other touching the reinforcement as shown in Fig. 1. Surface column temperatures were measured using three additional thermocouples; one at the mid column height and the other two were located at $300 \mathrm{~mm}$ from the top and bottom of the column's ends. Axial column displacement was measured using four LVDTs (Linear Variable Displacement Transducer) two at the top and two at the bottom to ensure high precision in measurement. Two $400 \mathrm{kN}$ capacity load cells were used to measure the applied loads. The data were recorded using data logging system.

\section{Test Methodology}

A specially designed rig was used to apply loads on the columns. More details about that rig and its work mechanism and the furnace used in testing are shown in reference [4]. First, the column was set inside the furnace between the two simple supports at the top and the bottom. Then the load was applied in 10\% increments at constant rate until reaching the desired loading level. After that the burner was ignited and controlled to match the desired fire curve and the applied load was kept constant until the end of the test.

\section{Spalling Assessment}

To asses the severity of spalling three types of spalling were classified:

a) Minor spalling: concrete surface spalling without reaching the reinforcement.

b) Major spalling: spalling reaches the steel reinforcement and leaves it exposed.

c) Severe spalling: concrete spalling that reaches high depths inside the steel reinforcing cage and happens with very high explosive energy.

The other criteria used to asses spalling is the degree of spalling:

$$
\text { Spalling Degree }=\frac{\mathrm{W}_{\mathrm{L}}}{\mathrm{W}_{\mathrm{C}}}
$$

Where $\mathrm{W}_{\mathrm{L}}$ is the concrete mass lost due to spalling, $\mathrm{W}_{\mathrm{C}}$ is the total column mass before testing. If the spalling degree for a column $=0.3$ it means that $30 \%$ of the column mass was lost due to spalling. 


\section{TESTS RESULTS}

\section{Individual Cases}

Almost all the eighteen columns tested behaved in a similar way but they differed in the values and the mode of failure according to the test condition. For purposes of illustration two cases of high applied loading level = 0.6 will be discussed.

One with high heating rate (column HH15) and the second with low heating rate (column HH17) (see Table 2). Fig. 3 shows temperatures development with time for column surface, column center and reinforcement of column HH15. The Figure illustrates also the time periods where concrete spallings took place. During the test, explosive spallings happened between minute 5 and minute 22 and no spalling took place after that time. A similar spalling time pattern was noticed in all the performed tests. Figure 4 shows the development of axial displacement of the column HH15 during heating. For the first $400^{\circ} \mathrm{C}$ (the first 1 minute) small expansion was recorded, then the axial displacement started to increase in a reasonably high rate until reaching a maximum value of $0.825 \mathrm{~mm}$ at column surface temperature $=678^{\circ} \mathrm{C}$ after 16 minutes. Then the displacement started to decline rapidly at a higher rate until reaching the original (before heating) position after 29 minutes at $729^{\circ} \mathrm{C}$ column surface temperature when a column buckling took place. It is important to emphasize here that column buckling was mainly due to the major parts of the column section lost due to concrete spalling in critical positions near the mid height of the column. The degree of spalling for this case was 0.16 (see Table 2).

The next test considered is column HH17 tested under low heating rate. Fig. 5 shows the temperature curves and the spalling periods. Only minor spallings took place between 17 and 36 minutes. The axial displacement development showed in Figure 6 has a similar trend to that of column HH15 but the maximum axial displacement value of $0.872 \mathrm{~mm}$ was reached at $485^{\circ} \mathrm{C}$ column surface temperature after 33 minutes and the failure happened after 63 minutes at column surface temperature of $623^{\circ}$ C. No column buckling took place as the spallings were minor and the spalling degree was only 0.01. It is important to point out here that the maximum axial displacement values were close to each other in both heating cases and the higher value was recorded in case of low heating rate.

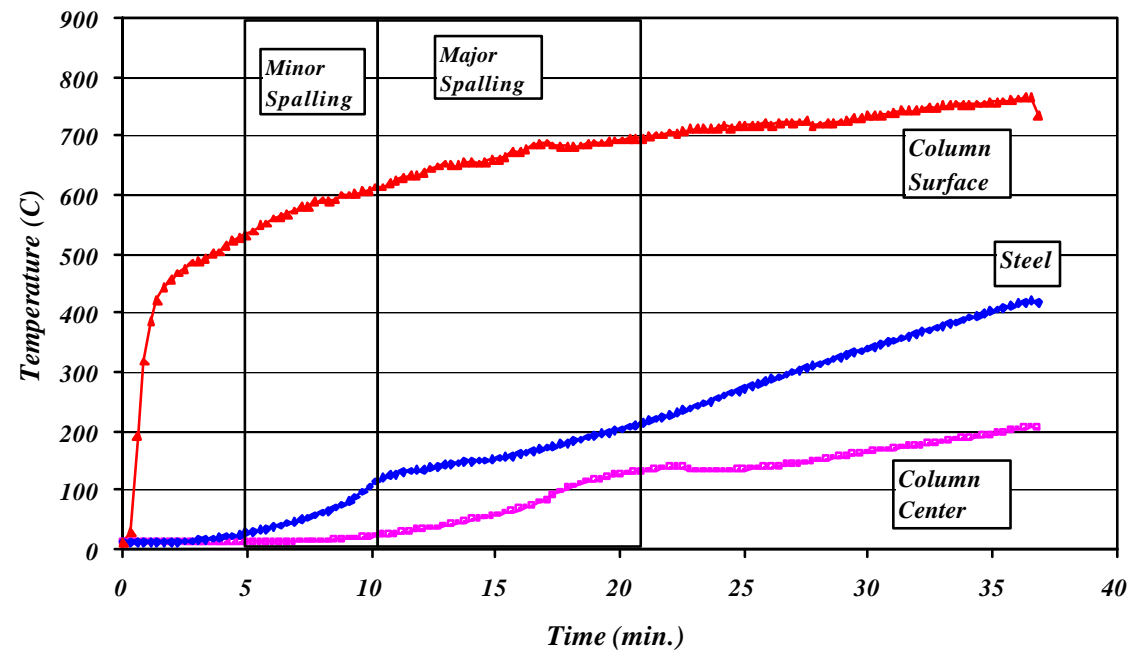

Figure 3. Temperature development with time for column HH15 


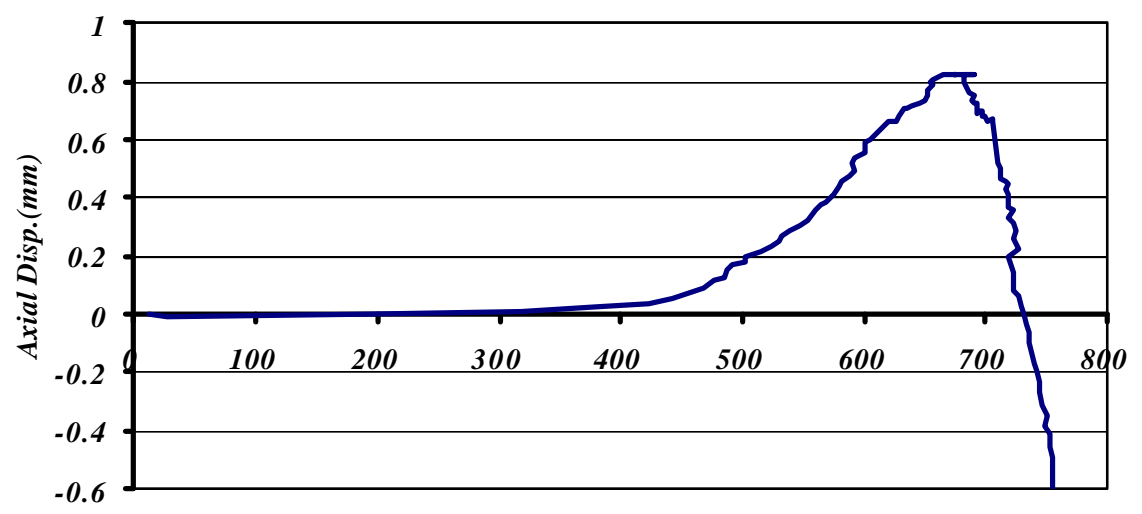

Column Surface Temperature (C)

Figure 4. Axial Displacement recorded for column HH15

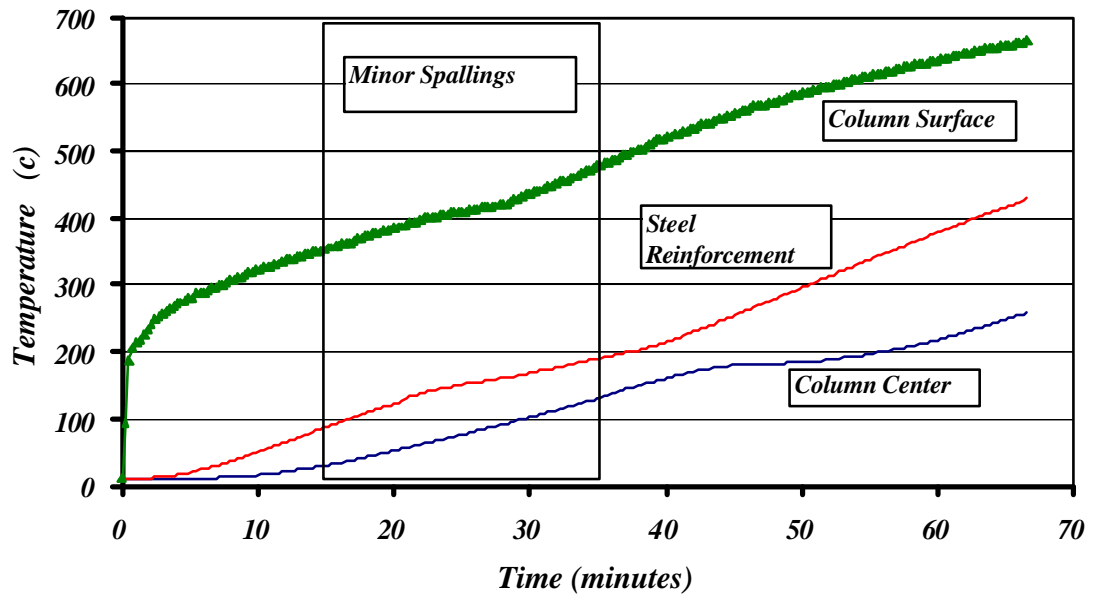

Figure 5. Temperature development with time for column HH17 


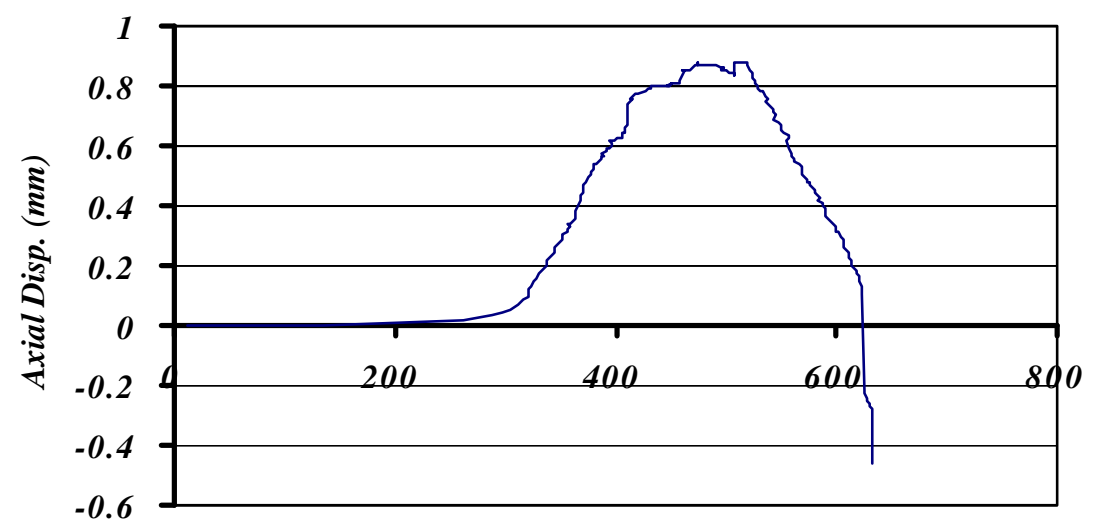

Column Surface Temperature (C)

Figure 6. Axial displacements recorded for column HH17.

\section{Overall Tests Results}

The main outcome of the 18 fire tests are shown in Table 2. In this Table, spalling types and degrees together with failure temperatures and time are presented. By examining each case it is clear that despite the good agreement in the measured parameters an obvious deviation in the values of spalling degrees can be noticed between the three tested specimens for each case. Perhaps, this is not surprising in a concrete experimental investigation particularly when such a random phenomenon like spalling is studied [3,6]. This was the reason behind testing three specimens for each case. For example, there is a clear difference between the values of spalling degrees of the two specimens $\mathrm{HH} 1, \mathrm{HH} 2$ and the third specimen $\mathrm{HH} 3$ and for purposes of data analysis specimens HH3 is ignored. Therefore, columns HH3; HH6; HH13 and HH16 are excluded and the average of the remaining test specimens is considered

Table 2. Fire Test Results

\begin{tabular}{|c|c|c|c|c|c|c|c|c|}
\hline Ref. & Specimen & Loading level & $\begin{array}{c}\text { Heating } \\
\text { Rate }\end{array}$ & $\begin{array}{c}\text { Spalling } \\
\text { Type }\end{array}$ & \begin{tabular}{|c} 
Spalling \\
Degree
\end{tabular} & $\begin{array}{c}\text { Failure } \\
\text { Time }(m)\end{array}$ & $\begin{array}{c}\text { Failure } \\
\text { Temp. } *(C)\end{array}$ & $\begin{array}{c}\text { Failure } \\
\text { Mode }\end{array}$ \\
\hline HH1 & One & \multirow{6}{*}{0.2} & \multirow{3}{*}{ High } & Major & 0.2 & 39 & 991 & Buckling \\
\hline $\mathrm{HH} 2$ & Two & & & Major & 0.16 & 44 & 900 & Buckling \\
\hline $\mathrm{HH} 3$ & Three & & & Minor & 0.01 & No & No & -- \\
\hline HH3 & One & & \multirow{3}{*}{ Low } & Minor & 0.01 & No & No & -- \\
\hline HH5 & Two & & & Minor & 0.02 & No & No & -- \\
\hline HH6 & Three & & & Major & 0.27 & 70 & 766 & Buckling \\
\hline HH7 & One & \multirow{6}{*}{0.4} & \multirow{3}{*}{ High } & Severe & 0.39 & 31 & 806 & Buckling \\
\hline HH8 & Two & & & Minor & 0.11 & No & No & -- \\
\hline HH9 & Three & & & Severe & 0.26 & 37 & 872 & Buckling \\
\hline HH10 & One & & \multirow{3}{*}{ Low } & Severe & 0.48 & 37 & 598 & Buckling \\
\hline HH11 & Two & & & Severe & 0.54 & 40 & 698 & Buckling \\
\hline HH12 & Three & & & Severe & 0.54 & 45 & 684 & Buckling \\
\hline HH13 & One & \multirow{6}{*}{0.6} & \multirow{3}{*}{ High } & Minor & 0.02 & 26 & 831 & -- \\
\hline HH14 & Two & & & Severe & 0.13 & 25 & 810 & Buckling \\
\hline HH15 & Three & & & Severe & 0.16 & 29 & 834 & Buckling \\
\hline HH16 & One & & \multirow{3}{*}{ Low } & Severe & 0.65 & 46 & 647 & Buckling \\
\hline HH17 & Two & & & Minor & 0.01 & 63 & 727 & -- \\
\hline HH18 & Three & & & No & 0 & 56 & 708 & -- \\
\hline
\end{tabular}


The relationship between failure time and loading level for two heating rates is plotted using data in Table 2 and shown in Fig. 7. The Figure shows that increasing the loading level decreased failure time in both heating cases. The same conclusion can be drawn on failure temperatures. Figure 8 shows scattered experimental points representing the effect of loading level on the spalling severity expressed by spalling degree values. By plotting the best straight line fit to the scattered test data in Fig. 8 a general conclusion can be drawn, that increasing the loading level did not increase the risk of spalling. Despite that the experimental points in Figure 8 indicate an increase in the degree of spalling at loading levels $=0.4$ for both heating levels, such a conclusion cannot be adopted until further investigating tests are carried out for both heating regimes, perhaps for loading levels 0.3 and 0.5 . Fig. 8 shows also that high strength concrete columns are less susceptible to spalling under low heating rates. Fig. 9 shows the picture of one of the columns where the core was smashed due to spalling

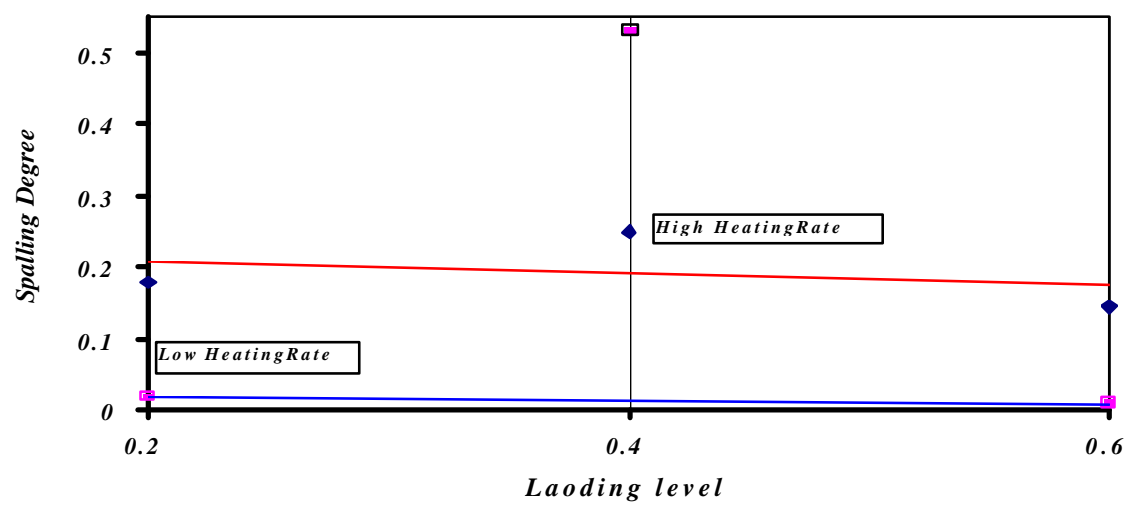

Figure 7. Effect of loading and heating rate on fire resistance

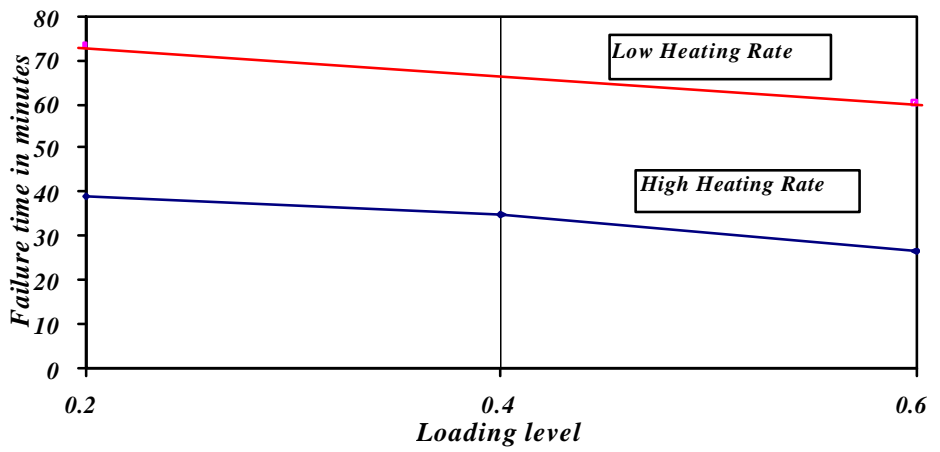

Figure 8. Effect of loading level and heating rate on degree of spalling 


\begin{abstract}
ADDITIONAL TESTS
In order to investigate more specifically the effect of loading on columns spalling and to obtain more accurate conclusions on this issue, additional 12 high strength concrete columns were tested. Six columns were tested under 0.3 loading level (three specimens were tested under the high heating curve, the other three columns were tested under the low heating regime shown in Fig. 2). The other six columns were tested at the same heating rates but at 0.5 loading level. It was anticipated that the results of the previous and the additional tests would allow better analysis of the behavior of columns at five loading levels $0.2,0.3,0.4,0.5$ and 0.6 each at two heating rates. All the parameters involved in the additional tests are the same as for the previous tests. Performing the additional tests showed that six columns had spalling (tested under high heating rate) and the other six columns (tested under low heating rate) did not suffer from spalling. The outcome of the additional tests is show in Table 3.
\end{abstract}

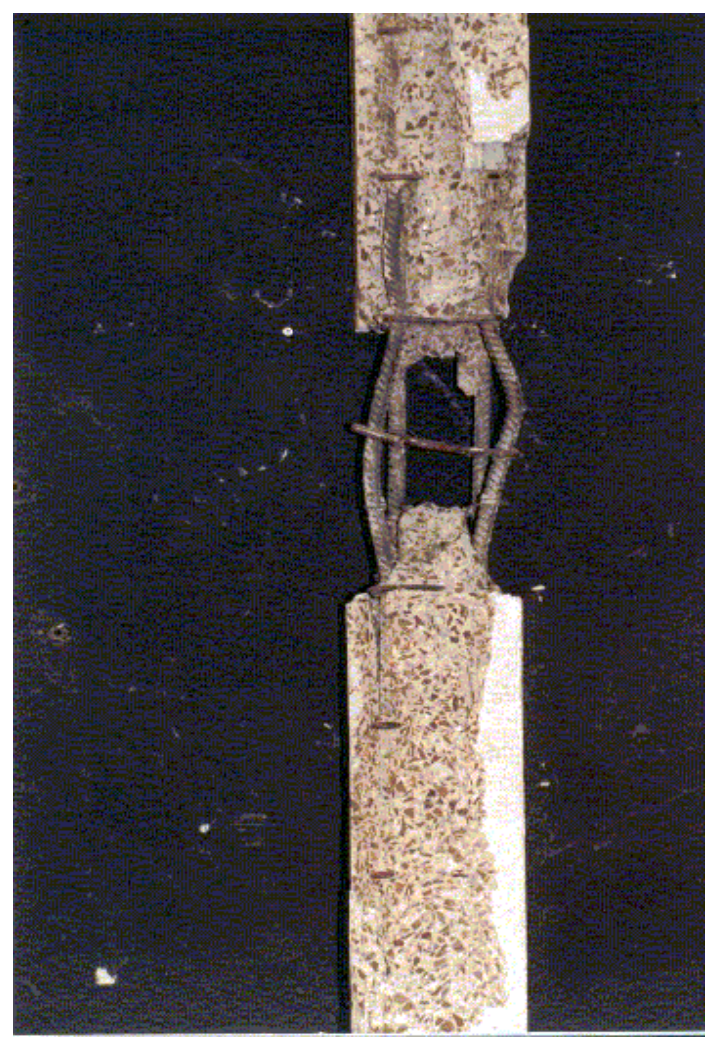

Figure 9. Concrete column damaged severely by explosive spalling 
Table 3. Results for the additional fire tests.

\begin{tabular}{|c|c|c|c|c|c|c|c|}
\hline Ref. & Specimen & Loading level & $\begin{array}{c}\text { Heating } \\
\text { Rate }\end{array}$ & $\begin{array}{c}\text { Spalling } \\
\text { Type }\end{array}$ & $\begin{array}{c}\text { Spalling } \\
\text { Degree }\end{array}$ & $\begin{array}{c}\text { Failure } \\
\text { Time }(M)\end{array}$ & $\begin{array}{c}\text { Failure } \\
\text { Temp. } *(C)\end{array}$ \\
\hline $\mathrm{HH} 4 \mathrm{~A}$ & One & \multirow{3}{*}{0.3} & \multirow{3}{*}{ High } & Major & 0.11 & 54 & 991 \\
\hline HH5A & Two & & & Major & 0.05 & 57 & 900 \\
\hline HH6A & Three & & & Minor & 0.06 & 57 & No \\
\hline HH4B & One & \multirow{3}{*}{0.3} & \multirow{3}{*}{ Low } & --- & 0 & 108 & No \\
\hline HH5B & Two & & & --- & 0 & 103 & No \\
\hline HH6B & Three & & & --- & 0 & 92 & 766 \\
\hline HH7A & One & \multirow{3}{*}{0.5} & \multirow{3}{*}{ High } & Minor & 0.11 & 38 & 806 \\
\hline HH8A & Two & & & Minor & 0.02 & 36 & No \\
\hline HH9A & Three & & & Minor & 0.08 & 35 & 872 \\
\hline HH7B & One & \multirow{3}{*}{0.5} & \multirow{3}{*}{ Low } & --- & 0 & 63 & 598 \\
\hline HH8B & Two & & & --- & 0 & 72 & 698 \\
\hline HH9B & Three & & & --- & 0 & 63 & 684 \\
\hline
\end{tabular}

The test data in Table 3 show excellent compatibility and minor differences. Figure 10 and 11 show the effect of loading level on the degree of spalling both for high and low heating rates. These two Figures represent all the test results including those obtained from the further 12 tests. Fig. 10, 11 and Table 3 confirmed the previous conclusion stated that the loading level has no significant effect on the degree of spalling. The other confirmed conclusion is that higher heating rates increase the probability of spalling.

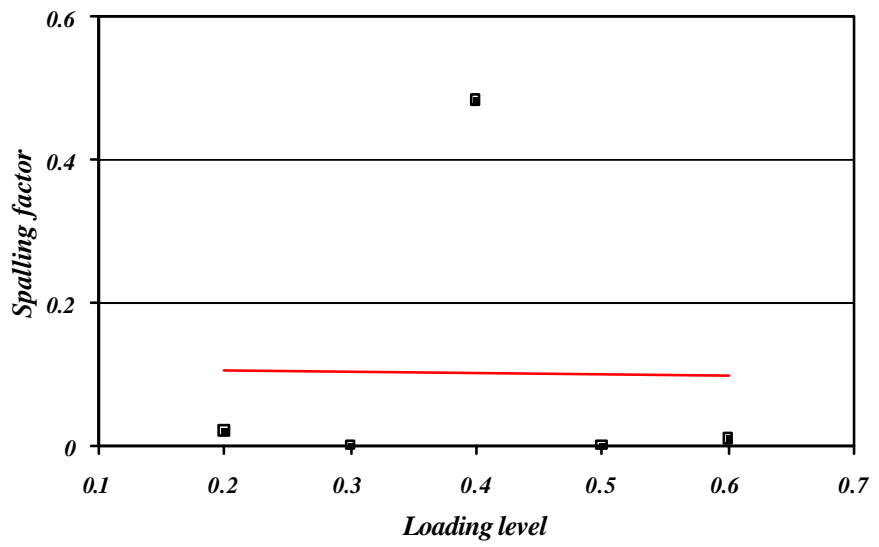

Figure 10. Effect of loading level on degree of spalling under high heating rate. 


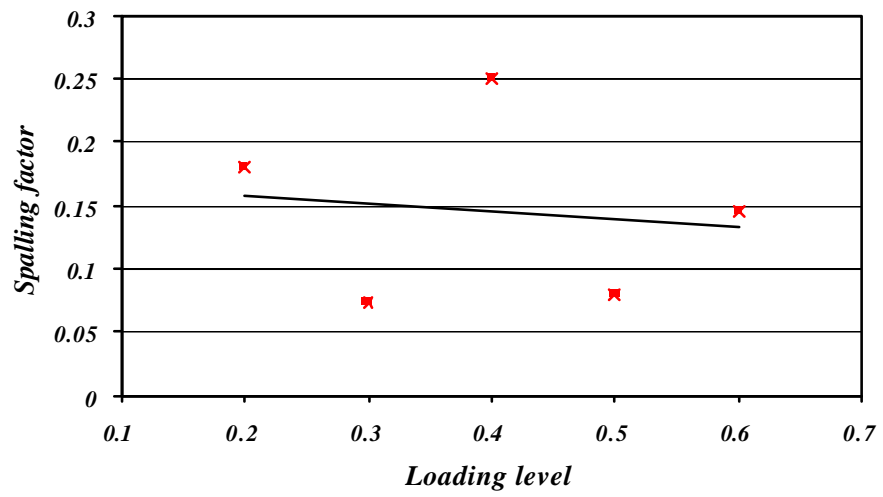

Figure 11. Effect of loading level on spalling degree under low heating

\section{CONCLUSIONS}

1) Among 18 columns tested under different loads and heating regimes 17 columns suffered various types of spalling. All the spallings were explosive.

2) In all the tests, explosive spalling happened in a period up for 45 minutes of heating. Always minor spallings took place first followed by major and severe spallings. Explosive spalling never happened at late heating time.

3) It was noticed that explosive spalling always occurs when the column is expanding. No spalling took place in columns in the contraction phase.

4) Low heating rates minimized the risk of explosive spalling.

5) Tests showed that loading levels up to $60 \%$ of the design strength have no significant effect on the probability of concrete spalling both under high and low heating rate.

6) Columns tested under high heating showed less fire resistance.

7) Explosive spalling may have very severe impact on the surrounding environment. Pieces of smashed concrete can fly with high speed and explosive energy causing more severe casualties.

8) Explosive spalling could cause premature column failure (buckling) as major parts of the columns section can be lost due to spalling.

9) Additional 12 columns were tested to verify the obtained conclusion and to enhance the testing program. The outcome of these additional tests confirmed the conclusions mentioned in 4 and 5 above and showed a good compatibility with the previous performed tests. 


\section{REFERENCES}

1. Akhtaruzzaman A. and Sullivan P. J. E. "Explosive Spalling Of Concrete Exposed To High Temperature." Imperial College of Science and Technology, Concrete Structures and Technology, Research report CSTR 70/2. London, the College, December, 24 pp, 1970.

2. Aldea C-M, Franssen JM, and Dotreppe JC. "Fire Tests On Normal And High Strength Reinforced Concrete Columns", Nist website, Internet, pp109-117,1997.

3. Ali F. A., Connolly R. , and Sullivan P. J. E. "The Spalling Of High Strength Concrete At Elevated Temperatures." Journal Of Applied Fire Science, Vol. 6, No. 1, 1997.

4. Ali F. A., Randall M., Simms I., O'connor D., P. Shepherdes And Ian Burgess. The effect of axial restraint on the fire resistance of steel columns. Journal of Constructional Steel Research, Vol. 98, paper No. 177, special edition of The Second World Conference, San Sebastian, Spain, May, 1998.

5. Castillo C. and A. J. Durrani. "Effect Of Transient High Temperature On High Strength Concrete." ACI Materials Journals, Vol. 87, No. 1 Jan-Feb 1990.

6. Connolly R. J. “Spalling Of Concrete In Fire.” PhD Thesis, University of Aston, Birmingham April, p.288, 1995.

7. Copier W. J. “The Spalling Of Normal Weight And Light Weight Concrete Exposed To Fire.” Journal of The American Concrete Institute. Vol. 80, No. 4, p. 352-353, 1983

8. Diederchis U., UM, Jumppananen., and U. Schenieder," High Temperature Properties And Spalling Behaviour Of High Strength Concrete." Proceedings of the $4^{\text {th }}$ Wiemer Workshop on High Strength Concrete." Material properties and design, p. 219-236, 1995.

9. Dougill, J.W. "The effect of high temperature on concrete with reference to thermal spalling". $\mathrm{PhD}$ Theses, Imperial college, London, 1970

10. Hertz K. D. "Danish Investigations On Silica Fume Concretes At Elevated Temperatures." ACI Materials Journals, V. 89, No. 4, p. 345-347, 1992.

11. Jumppanen U-M. "Effect Of Strength On Behavior Of Concrete" Magazine Of Concrete Research, Vol. 8, p.116-127, 1998.

12. Lennon T., And Clayton N.” Program To Investigate The Performance Of High Strength Concrete In Fire, With Particular Reference To Explosive Spalling". BRE LTD Report. FG 2837, (Note N23/98), March, 1998.

13. Malhotra H. L. "Spalling Of Concrete In Fires." Technical report 118. Construction Industry Research and Information Association, London, 1984.

14. Meyer-Ottens C. "The Question Of Spalling Of Concrete Structural Elements Of Standard Concrete Under Fire Loading.” PhD Thesis, Technical University of Braunschwei. Germany, 1972.

15. Sanjayan G. and Stocks L. J. "Spalling Of High-Strength Silica Fume Concrete In Fire." ACI Materials Journal V. 90 No. 2, March-April, 1993.

16. Shirley T., Burg R. G. and Fiorato A. E. "Fire Endurance Of High-Strength Concrete Slabs." ACI Materials Journal V.85, No. 2, March-April, p. 102-108, 1988. 